\title{
PENGATURAN PENDIRIAN PERUSAHAAN PENANAMAN MODAL ASING (PMA) DI INDONESIA
}

\author{
Gusti Ngurah Sudarma Yuda, I Nyoman Putu Budiartha, Ni Made Puspa Sutari Ujianti \\ Fakultas Ilmu Hukum Universitas Warmadewa, Denpasar-Bali, Indonesia \\ haman@gmailcom, budiarthaputu59@gmailcom, puspa@gmailcom
}

\begin{abstract}
Abstrak
Penanaman modal atau investasi memiliki fungsi yang teramat penting perihal akan meningkatkan perkembangan keadaan perekonomian negara. Penanaman modal ini adalah suatu kegiatan yang dilakukan oleh dunia usaha dalam rangka meningkatkan taraf hidup masyarakat. Penelitian bertujuan untuk menjelaskan pengaturan perjanjian pendirian perusahaan penanaman modal asing diera otonomi daerah dan mendeskripsikan penyelesaian sengketa dalam penanaman modal asing. Metode Penelitian menggunakan penelitian hukum normatif dengan pendekatan masalah menggunakan pendekatan perundang-undangan dan pendekatan konseptual. Adapun sumber data yang digunakan adalah bahan hukum primer dan sekunder. Hasil penelitian ini menunjukan keberadaan PMA pada masa otonomi daerah kebijakan yang diambil BKPMD/ BPM Provinsi Bali guna menarik para investor dalam melakukan suatu investasinya di daerah Bali khususnya maka BKPMD/BPM Provinsi Bali masih berpedoman pada Surat Deputi Bidang Pengembangan Pengusahaan Nasional BPM Nomor S-35/DU-5BKPM/2001 tentang bidang promosi dan kerjasama internasional penanaman modal dan penyelesaian sengketa bagi penanaman modal asing yang melakukan pelanggaran menurut Undang-Undang Nomor 25 Tahun 2007 ditempuh dengan cara di luar peradilan umum (non litigasi) melalui arbitrase dan cara melalui peradilan (litigasi).
\end{abstract}

Kata kunci: Modal, Penanaman Modal Asing, Pendirian Badan Usaha

\begin{abstract}
Investment has a very important function in terms of improving the development of the state's economy. This investment is an activity carried out by the business world in order to improve the standard of living of the community. The research aims to explain the arrangement of agreements for the establishment of foreign investment companies in the era of regional autonomy and to describe the settlement of disputes in foreign investment. The research method was normative legal research with a problem approach using a statutory approach and a conceptual approach. The data sources used were primary and secondary legal materials. The results of this study indicatde the existence of PMA during the regional autonomy era, the policies taken by the Bali Provincial BKPMD / BPM to attract investors to invest in the Bali area, especially the Bali Province $B K P M D$ / BPM are still guided by the Letter of the Deputy for National Entrepreneurship Development, BPM Number S-35. / DU-5BKPM / 2001 concerning the field of promotion and international cooperation in investment and dispute resolution for foreign investment who commit violations according to Law Number 25 of 2007 is pursued by means outside the general court (non-litigation) through arbitration and through the judiciary ( litigation).
\end{abstract}

Keywords: Capital, Foreign Investment, Establishment of Business Entities

\section{PENDAHULUAN}

Pemerintah menjalin hubungan dengan berbagai negara untuk memperoleh pinjaman ekuitas dan kerja sama dalam penanaman modal keseimbangan kebijakan luar negeri dan strategi manajemen yang bebas dan aktif harus diupayakan dengan baik Manajemen harus mencari antara lain bentuk investasi yang memberikan harapan keuntungan setinggi-tingginya (Kartasapoetra, Kartasapoetra, Kartasapoetra, \& Setiady, 2005).

Sehubungan dengan kepastian hukum, Indonesia saat ini sedang menghadapi tantangan berat dimana perkembangan yang cepat dalam pasar global sering kali menyebabkan hukum tertinggal di belakang, perkembangan dan pembangunan ekonomi harus disesuaikan dengan hukum yang memadai agar tidak terjadi kerancuan-kerancuan dalam menciptakan suatu bisnis yang sehat (Zaini, 2012); (Hapsari, 2019). Dalam upaya menanggulangi ketertinggalan hukum maka saran yang harus ditempuh 
oleh pihak pemerintah adalah dengan mengeluarkan deregulasi di berbagai bidang perekonomian. Setelah diberlakukannya Undang-Undang Republik Indonesia Nomor 22 Tahun 1999 sebagaimana telah diganti dengan Undang-Undang Republik Indonesia Nomor 32 Tahun 2004 tentang Pemerintah Daerah (selanjutnya disebut UU Pemda) kewenangan investasi (penanaman modal) menjadi kewenangan pemerintah Kabupaten/Kota.

Secara umum wilayah kewenangan pemerintah kabupaten/kota meliputi pekerjaan umum kesehatan pendidikan dan kebudayaan pertanian perhubungan perindustrian dan perdagangan penanaman modal lingkungan hidup pertanahan koperasi dan sumber daya manusia (Martono, 2005). Namun masuknya perusahaan asing ke Indonesia terutama kegiatan penanaman modal yang masuk ke daerah pada era otonomi daerah bertujuan untuk melengkapi sektor komersial dan industri yang belum sepenuhnya dilaksanakan oleh swasta negara karena alasan seperti teknologi manajemen atau permodalan. Selain itu diharapkan secara langsung maupun tidak langsung dapat menstimulasi dan merangsang lingkungan atau kehidupan usaha di berbagai bidang perdagangan serta dapat memanfaatkan modal asing untuk menembus jaringan pemasaran internasional melalui jaringannya. Pada era otonomi daerah PMA diinginkan secara nyata akan dapat mempersingkat waktu tentang proses menata perekonomian. Eksistensi PMA di era otonomi daerah erat kaitannya dengan kebijaksanaan atau instrumen hukum yang dilakukan oleh BKPMD/BPM dalam meningkatkan iklim PMA pada era otonomi daerah, kebijakan yang diambil BKPMD/BPM Provinsi Bali guna menarik para investor dalam melakukan suatu investasinya di daerah Bali khususnya.

Ada beberapa penelitian terdahulu yang melakukan penelitian terkait penelitian ini, yaitu (Sari, 2020); (Devi, 2019) dan (Billa, Wahongan, \& Gosal, 2020) mengkaji tentang perlindungan hukum bagi penanaman modal asing (PMA) di Indonesia serta membahas tentang Syarat- penanaman modal asing (PMA) di Indonesia sesuai Undang-Undang Nomor 25 Tahun 2007 tentang penanaman modal. Sekalipun sudah banyak peneliti sebelumnya telah melakukan penelitian ini, namun sampai saat ini diketahui bahwa di Indonesia penanaman masih menjadi masalah. Oleh sebab itu penelitian ini dilakukan dengan cara penyajian masalah yang berbeda. Adapun tujuan penelitian ini yaitu menjelaskan pengaturan perjanjian pendirian perusahaan penanaman modal asing diera otonomi daerah dan mendeskripsikan penyelesaian sengketa dalam penanaman modal asing.

\section{METODE}

Penelitian ini didesain dengan penelitian hukum normatif yaitu penelitian dilakukan dengan menganalisis peraturan perundang-undangan yang berlaku (Hartono, 1994). Sumber bahan hukum yang digunakan terbagi atas bahan hukum primer adalah bahan hukum yang utama yang menjadi dasar kajian masalah yang diteliti, bahan hukum sekunder adalah adalah bahan hukum yang digunakan untuk menunjang atau membantu dalam memberikan pemahaman-pemahaman dan gambaran-gambaran serta teori-teori hukum yang digunakan untuk mengulas dan memecahkan persoalan-persoalan yang akan diteliti, selanjutnya bahan hukum tersier adalah bahan hukum yang memberikan pedoman dan interpretasi bagi bahan hukum tingkat pertama dan kedua. Untuk memperoleh bahan hukum primer, sekunder dan tersier maka teknik inventarisasi atau penelusuran bahan hukum yang bersangkutan kemudian diklasifikasikan dan dianalisis menggunakan pendekatan kualitatif (Sugiyono, 2013).

\section{HASIL DAN PEMBAHASAN}

\section{Pengaturan Perizinan Pendirian Perusahaan Penanaman Modal Asing Diera Otonomi Daerah}

Pasang surut suatu kegiatan investasi selain banyak dipengaruhi oleh faktor internal baik itu potensi alam demografi dan berbagai deregulasi juga sangat dipengaruhi oleh faktor eksternal. Faktor eksternal dapat menyebabkan turunnya jumlah modal yang dialokasikan dari negara-negara maju ke negara berkembang. Perkembangan investasi di Indonesia masih didominasi oleh negara-negara asia timur. Berkurangnya arus investasi disebabkan oleh beberapa negara maju sedang mengalokasikan sebagian dananya untuk sifat sosial di samping itu juga Indonesia menghadapi tawaran dari negara asing. Berdasarkan ketentuan Undang-Undang ini dan aturan pelaksanaannya badan hukum yang didirikan berdasarkan perjanjian membagi seluruh saham menjadi saham bermodal hukum (Jaya, 2004). Usaha atau investor yang menanamkan modalnya di Indonesia mendirikan suatu badan hukum yang berdasar atas hukum Indonesia yakni Perseroan Terbatas yang telah memiliki perangkat sendiri yakni Undang-Undang Republik Indonesia Nomor 40 Tahun 2007. PT dahulunya merupakan bagian 
dari KUHD (Wetboek van Koophandel dalam bahasa Belanda yang disingkat WvK) kemudian lambat laun mengalami penyesuaian dengan keadaan kemajuan atau perkembangan pertumbuhan ekonomi. Oleh karena itu diperlukan investasi asing (PMA) dari negara berkembang untuk mempersingkat waktu penataan ekonomi. Investasi Asing berkontribusi pada industrialisasi pembangunan modal dan penciptaan lapangan kerja serta keterampilan teknis melalui investasi asing ia telah membuka ladang baru dan memanfaatkan sumber daya baru, hal ini juga mencakup risiko dan kerugian pada fase permulaan dan investasi asing selanjutnya mendorong pengusaha lokal untuk bekerja sama modal asing juga akan membantu mengurangi masalah neraca pembayaran dan inflasi yang akan memperkuat negara tuan rumah atau negara yang biasa disebut sebagai host country

\section{Penyelesaian Sengketa Penanaman Modal Asing Penyelesaian Sengketa dengan Cara di Luar Peradilan Umum (Non Litigasi)}

Istilah arbitrase berasal dari bahasa Indonesia yang artinya perselisihan dapat diselesaikan sesuai dengan kebijakan. Suatu arbitrase pada hakikatnya merupakan suatu usaha damai untuk menyelesaikan sengketa yang timbul antara dua pihak atau lebih dengan menyerahkan sengketa tersebut untuk diselesaikan secara final, setelah kedua belah pihak didengar melalui tata cara yurisial oleh satu atau beberapa orang wasit (arbiter). Kekuasaan untuk menyelesaikan menurut kebijakan itu seyogyanya tidak ditafsirkan secara harfiah saja, karena hal ini akan menimbulkan kesalahpahaman seolah-olah arbiter tidak patuh pada norma hukum dalam menyelesaikan perselisihan dan mendasarkan keputusannya pada kebijakan subjektif.

Teori ini kurang tepat karena arbiter atau majelis arbitrase juga menerapkan hukum seperti halnya hakim atau pengadilan (Subekti, 1981). Arbitrase termasuk hukum acara atau hukum proses mengenai perselisihan-perselisihan privat baik nasional maupun internasional karena itu dalam arbitrase dikenal arbitrase nasional atau juga disebut arbitrase domestik dan arbitrase internasional khusus dalam bidang privat.

Di Indonesia selain lembaga peradilan penyelesaian sengketa yang paling populer adalah melalui lembaga arbitrase. Selain arbitrase dan lembaga pengadilan masih banyak cara lain untuk menyelesaikan sengketa yaitu

1. Arbitrase

2. Negosiasi

3. Mediasi

4. Konsiliasi

5. Pencari Fakta

6. Minitrial

7. Ombudsman

8. Penilaian Ahli

9. Pengadilan Kasus Kecil (Small Claim Court)

10. Peradilan Adat

Penyelesaian sengketa dengan cara melalui peradilan umum (litigasi) beberapa model penyelesaian sengketa di luar pengadilan dijelaskan sebagai berikut:

1. Arbitrase

Seperti disebutkan sebelumnya arbitrase mengacu pada metode penyelesaian sengketa pribadi di luar pengadilan publik berdasarkan kontrak arbitrase tertulis para pihak di mana para pihak memilih para pihak untuk menyelesaikan sengketa tersebut. Mereka yang tidak tertarik dengan kasus yang terlibat akan ditinjau dan diputuskan untuk sengketa tersebut Meski dianggap sebagai biaya yang cepat dan murah untuk menyelesaikan sengketa melalui arbitrase sebenarnya butuh waktu lama dan biaya perkara yang diakibatkannya pun semakin meningkat

2. Negosiasi

Negosiasi adalah proses negosiasi atau negosiasi tawar-menawar atas masalah tertentu yang terjadi di antara para pihak negosiasi dalam situasi ada perselisihan di antara kedua pihak dan tidak ada perselisihan karena masalah tersebut tidak pernah dibahas. Negosiasi sederhana adalah negosiasi yang hanya dilakukan oleh pihak terkait. Pada saat yang sama negosiasi yang kompleks akan melibatkan negosiator khusus seperti pengacara sebagai negosiator dan setiap orang memiliki negosiatornya sendiri. 
3. Mediasi

Mediasi adalah proses penyelesaian perselisihan di mana pihak luar yang netral dan tidak memihak menyelesaikan perselisihan dalam bentuk perundingan. Pihak eksternal akan kerja sama dengan pihak yang berselisih untuk membantu mencari solusi atas perselisihan tersebut dan memuaskan kedua belah pihak. Pihak ketiga yang netral disebut memediator . Tanggung jawab utama mediator adalah membuat forum seperti mengundang rapat, menampung dan mentransfer informasi, membelah masalah dan mengusulkan keputusan / solusi (jika tidak ada solusi yang ditemukan)

4. Konsiliasi

Rekonsiliasi mirip dengan mediasi. Mediasi juga merupakan proses penyelesaian sengketa dalam bentuk negosiasi dengan pihak luar yang netral dan adil untuk menyelesaikan masalah. Pihak eksternal akan bekerja sama dengan pihak yang berselisih untuk membantu mencari solusi yang dapat memuaskan kedua belah pihak. Pihak ketiga yang netral disebut mediator.

Penyelesaian sengketa dengan cara melalui peradilan umum (litigasi) dalam hal mendorong penanaman modal khususnya penanaman modal asing di Indonesia perlu disusun regulasi yang mendorong dan memberikan segala kemudahan bagi penyelenggaraan penanaman modal. Adanya peraturan pemerintah untuk penyelesaian sengketa penanaman modal asing di Indonesia dikukuhkan dengan disahkannya Konvensi Bank Dunia dengan Undang-Undang Republik Indonesia Nomor 5 Tahun 1958 lalu Tahun 1981 dan Ketetapan Mahkamah Agung Republik Indonesia Nomor 1 Tahun 1990. Oleh karena itu secara hukum Indonesia merasa terikat dengan ketentuan yang terdapat dalam konvensi, oleh karena itu setiap sengketa investasi atau penyelesaian sengketa akan dilakukan sesuai dengan prosedur yang diatur dalam International Convention on Dispute Resolution (ICSID).

Bentuk dan sifat teknis peradilan biasanya mengarah pada penyelesaian sengketa yang berlarutlarut yang membutuhkan waktu lama. Selain itu dalam sengketa komersial diperlukan penyelesaian sengketa yang cepat murah bersifat informal procedure. Waktu bagi seorang pelaku bisnis adalah sangat berharga Dengan teknologi informasi yang berkembang pesat dunia tidak lagi berlomba dengan waktu yang panjang tahun atau bulan tetapi hari jam dan menit sebagaimana dikatakan oleh William Irwin Thomson (Margono, 2000). Dengan meningkatnya aktivitas komersial tidak dapat dihindari untuk menghindari konflik atau perselisihan antara pihak-pihak yang terlibat Seperti biasa sengketa komersial akan diselesaikan melalui lembaga litigasi (melalui pengadilan) karena posisi para pihak saling bertentangan dan proses ini akan memakan waktu lama. Oleh karena itu proses penyelesaian dan penyelesaian sengketa bisnis kurang diminati karena tidak memenuhi persyaratan perkembangannya.

\section{SIMPULAN DAN SARAN}

\section{Simpulan}

Berdasarkan analisis data, hasil penelitian menunjukkan bahwa eksistensi penanaman modal asing diera otonomi daerah erat kaitannya dengan kebijaksanaan atau instrumen hukum yang dilakukan oleh BKPMD/BPM dalam meningkatkan iklim PMA di era otonomi daerah kebijakan yang diambil BKPMD/ BPM Provinsi Bali guna menarik para investor dalam melakukan suatu investasinya di daerah Bali khususnya, maka BKPMD/BPM Provinsi Bali masih berpedoman pada Surat Deputi Bidang Pengembangan Pengusahaan Nasional BPM Nomor S-35/DU-5BKPM/2001 tentang bidang promosi dan kerjasama internasional penanaman modal. Selanjutnya penyelesaian sengketa bagi penanaman modal asing yang melakukan pelanggaran. Sesuai Undang-Undang Nomor 25 Tahun 2007 ditempuh dengan cara di luar peradilan umum (non litigasi), melalui arbitrase dan cara melalui peradilan (litigasi).

\section{Saran}

Berdasarkan simpulan tersebut diatas, dapat dikemukakan saran yaitu diharapkan kepada pemerintah otonomi daerah agar mengembangkan iklim investasi lebih besar kepada pihak asing, membuat suatu perangkat aturan yang jelas terhadap investasi sehingga orang atau badan hukum asing dalam melakukan suatu investasi di daerah yang memiliki potensi dan tingkat perkembangan perekonomian jelas dan tidak berubah-ubah. Selanjutnya bagi masyarakat dengan meningkatkan ekspor baik kuantitas kualitas maupun diversifikasi komoditi menambah dan memperluas lapangan kerja yang 
diharapkan mampu menampung angkatan kerja yang cukup banyak jumlahnya serta memberikan kesempatan memiliki setidak-tidaknya kesempatan ikut serta memiliki dan mengelola perusahaan pengembangan teknologi termasuk dalam hal ini usaha alih keterampilan memeratakan pendapatan (income) masyarakat dalam rangka meningkatkan pertumbuhan kesejahteraan masyarakat.

\section{DAFTAR PUSTAKA}

Billa, W. D. U., Wahongan, A. S., \& Gosal, V. Y. (2020). Kajian Yuridis Mengenai Penanaman Modal Asing Melalui Pendirian Perusahaan PMA Menurut Undang- Undang Nomor 25 Tahun 2007. Lex Privatum, 8(3), 107-117.

Devi, R. S. (2019). Perlindungan Hukum Bagi Penanaman Modal Asing (PMA) di Indonesia. Jurnal Rectum, l(2), 142-153.

Hapsari, D. R. I. (2019). Hukum dalam Mendorong Dinamika Pembangunan Perekonomian Nasional Ditinjau dari Prinsip Ekonomi Kerakyatan. Jurnal Ilmiah Hukum, 26(2), 238-252.

Hartono, S. (1994). Penelitian Hukum di Indonesia pada Akhir Abad ke-20. Bandung: Alumni.

Jaya, I. N. B. (2004). Pelatihan Hukum Bisnis. Denpasar.

Kartasapoetra, A. G., Kartasapoetra, G., Kartasapoetra, R. ., \& Setiady, A. (2005). Manajemen Penanaman Modal Asing. Jakarta: Bina Aksara.

Margono, S. (2000). ADR \& Arbitrase Proses Pelembagaan dan Aspek Hukum. Bogor: Ghalia Indonesia.

Martono. (2005). Bank dan Lembaga Keuangan Lainnya. Yogyakarta: Liberty.

Sari, I. (2020). Syarat-Syarat Penanaman Modal Asing (PMA) di Indonesia Menurut Undang-Undang Nomor 25 Tahun 2007 tentang Penanaman Modal. Jurnal Ilmiah Hukum Dirgantara, 10(2), 50-75.

Subekti, R. (1981). Arbiter Perdagangan. Jakarta: Bina Cipta.

Sugiyono. (2013). Metode Penelitian Pendidikan Pendekatan Kuantitatif dan Kualitatif. Bandung: Alfabeta.

Zaini, Z. D. (2012). Perspektif Hukum Sebagai Landasan Pembangunan Ekonomi di Indonesia (Sebuah Pendekatan Filsafat). Jurnal Hukum, 28(2), 929-957. 